\title{
The Perfect Man: Perspectives on Masculinities Within Heterogeneous Traditions of Early India*
}

\author{
Smita Sahgala
}

\begin{abstract}
There is no manual on masculinity in early India and yet the idea of perfect man runs through Sanskrit, Pali, and Prakrit texts. That the Sanskrit traditions should construct an image of perfect man is understandable. There is thrust on virility and procreation; procreation of a son who would inherit land and carry the lineage further. Strong and healthy men were needed to protect society and for the purpose of production. While this is understandable in a tradition that emphasizes life of a householder, one does find the concept of a complete man a little paradoxical in literature of monastic traditions that promote celibate existence for their monks. The monks were also kept away from both productive activities as well as from the responsibility of providing security to others. The focus was clearly on acquisition of knowledge and spiritual ascension. So what could push the construction of the notion of a perfect man? A closer exploration of Buddhist and Jain texts makes the complexity comprehensible as would be revealed by the study.
\end{abstract}

\section{Keywords}

Masculinity, Buddhism, Jainism, relational construction, sexual deviants

"Masculinity" is a relatively unexplored area in early Indian history. Gender studies chose women as their subjects of analysis and left males and masculinities on the periphery for long. However, recently interest in masculinity studies has grown within feminist frame and influenced historical analysis as well. Assistance has been sought from disciplines such as Sociology and Political Science that had begun their investigations and paradigm constructions a little earlier. The historicity of the discourse, its location on temporal and spatial map however, remains pertinent.

The purpose of the paper is to attempt to comprehend "ideal masculine" images projected within monastic traditions of early India and reconcile their relevance to a celibate existence. Buddhism and Jainism, the two heterodox sects of early India, are often noted for their anti-Brahmanical stance. These are well known in their critique of ritualism and materialism at a time when Vedism came to be associated with growing sacrificial cults. Vedic texts delineated numerous rituals for the welfare of a householder: his prosperity, lineage, and general well-being. The growing karmakanda (ceremonial) tradition did find a note of dissent in Upanishads but was better formalized within Buddhism and Jainism. The heterodox sects associated themselves with lay followers, critiqued growing ritualism but their

aLady Shri Ram College, University of Delhi, India

Correspondent Author:

Smita Sahgal, Department of History, Lady Shri Ram College, University of Delhi, New Delhi, 110024, India 
ultimate goal was attainment of nirvana/nibban through pursuance of jnana (knowledge). The samghas (monasteries) provided monks opportunities to attain spiritual consciousness and dilute their gendered self. Ultimately the focus was neither on this world nor human body but on consciousness. That appears to be a common perception of both these monastic traditions. A closer study of literature and art may reveal something else. Both Buddha and Mahavira become visible as muscular and virile men. To many, the construction of the Buddha and the Mahavira as "perfect men" and norms emphasizing entry of only "complete men" to samghas appears a little ironical. Through this short historical study, it may be worth exploring the rationale behind the emphasis on perfect or complete manhood and seeking its compliance with the ultimate goal of nibbana.

We may have to start looking at the definition of masculinity and assess whether a term current in modern western academic world can have its relevance to our current study. We have to trace the way the spiritual heads of the two traditions came to be depicted in their texts. What were their notions of masculinity? Did these notions create stereotypes for their followers? Why should perfect masculinity be required for ensuing meditative practices? Were these any different from the Brahmanical projections of ideal men in domestic and spiritual domains? Was the masculinity projected in monastic traditions relational to women? How is male bonding/friendship envisaged in their literary texts? Do we get a sense of hierarchized masculine images from their literary repertoire? We shall try to look at such and related issues. Before we take up specific exploration on the issue of masculinity, let us define our historical contours and also arrive at a workable definition of masculinity in early Indian frame.

\section{HISTORICAL CONTOURS}

The focus of the work is largely on early India, that is, a period between sixth century BCE and early centuries of Common Era. The locale is north India, particularly eastern Uttar Pradesh and Bihar. Among the sources, we have the canon of the two heterodox traditions and later commentaries as our chief resources. The Buddhist commentaries of Buddhaghosha: Samantapasadika, and Asanga's Bodhisattva-Bhumi belong to early years of the Common period. We will also look at a Jain text of medieval times; especially the Yuktiprabodha of the Svetambara Upadhyaya Meghavijaya.

\section{TOWARDS A DEFINITION OF MASCULINITY}

Within conventional usage of the term, masculinity has emerged as one component of the binary; the other being femininity. It almost appears as a crux or commodity, which can be measured, possessed, or lost. More often than not, anatomy becomes the foundation of masculinity. It is the possession of "penis"/phallus on which the masculinity is supposedly grounded. The sexual and procreative functions have been cited as the most enduring characteristics of masculinity. The shorter Oxford Dictionary tells us that a "male" is "of or belongs to the sex that begets offspring, or performs the procreative function" and "masculine" has "the appropriate excellence of the male sex; virile, vigorous and powerful". Conversely, impotency, homosexuality, physical weakness, public exhibition of emotions and giving in to defeat would be reflective of "failed masculinity" or "feminized men". Femininity is by and large distinguished from masculinity on the basis of subordination of women to men. It may acquire different forms. One form is defined around compliance with this subordination and is oriented to accommodating the interests and desires of men, which is often called "emphasized femininity". Others are defined by strategies of resistance or forms of non-compliance (Connell 1987: 184). 
There is no discourse on masculinity per se in early Indian texts; however, the idea of masculinity does run through various texts. The first requirement is to work out a tentative definition based on different terms that we come across in the literature. Interestingly, the term "masculinity" does not occur in Monier-Williams' A Sanskrit-English Dictionary, though we do come across terms like "man" (purusha, vira) (Monier-Williams 1999: 1005), "manly" (paurushah, Viryogyah, virah, mahaviryah, narah) (Monier-Williams 1999: 481), and "manliness" (paurushama, viryam, parakrama, sahasam, surata, manusyatvam) (Monier-Williams 1999: 481). There are also words such as kimpurusa (evil man or a monkey like man) (Monier-Williams 1999: 283), khliba (Doniger and Smith 1991: 58), pandaka (passive homosexual), and na-pumsaka (non-man) that are construed in opposition to what has been understood as "manliness" in a larger question on masculinity. Remarkably, the binaries of masculine and feminine extend to homosexuals or those understood as hermaphrodites. There are references to congenital hermaphrodites or jatikhliba (Jaini 1991: 175) or non-congenital hermaphrodites, kritimakhliba (Jaini 1991: 177). The pervasiveness of such definitive terms that build a notion of masculinity on the basis of virility, strength, and bravery is hard to miss out and constitutes fundamental elements of definition of masculinity.

\section{BUDDHA, THE PERFECT MAN}

It is worth noting that the vast majority of Buddhist texts were written by, for, and about men, and the texts contain a wealth of material on cultural notions of normative manhood, the body, sexuality, and male sociality. Without doubt, these revolve primarily around the Buddha. Even as there is no way to know how Buddha really looked like, constructions did come up in the literary texts. In Pali texts, the Buddha is distinguished by two types of powers: wisdom power (jñanabala) and body power (kaya-bala). Most academic studies may have focused on wisdom but it is the assertion of some Buddhist scholars that, "the authors who created Buddha's character considered body power to be equally important" (Powers 2012: 8). There is no way that one can historically ascertain what the Buddha looked like but the composers of Buddhist texts created an image of his self that could fit in their own perception of a very masculine man. Hence, the Buddha is depicted as being skilled in archery, wrestling, and various martial arts, and as an extraordinary strong being, attractive to men, and admired by women. His body is adorned by 32 "physical characteristics of a great man" (mahapurushalakshana), which are found only on Buddhas and universal monarchs (Chakravartin) and are signs of their extraordinary accomplishments in past lives. He is referred to as Man-Lion and the four noble truths are his teeth and claws; his canines are the four Brahma abodes. Right from his birth to his upbringing in the royal place, from his ascetic training to his awakening in Bodh-Gaya and his defeats of demon Mara, the Buddha has been constructed as a man whose entire life demonstrated his complete and effortless mastery of all possible desirable masculine traits. Dighnikaya informs us that:

Among other things Buddha had flat feet: a thousand spoked wheeled pattern (chakra) on the soles of his feet and palms of his hands. His hands reached down to his knees without him having to bend over: webbed fingers and toes: soft and tender hands and feet: skin so smooth and delicate that no dust or dirt could settle on it: a curl of white hair in the middle of his forehead that when unwound reached to his elbows: a straight torso: legs like antelope's; a torso and Jaw like Lion's: eyelashes like a cow's: hair that grew one to each pore and curled to the right, along and wide tongue: a penis hidden by a sheath ${ }^{1}$.

Among the later texts, the Avadanas and Milindapanha-Tika mention 80 secondary physical characteristics (anuvyanjana) that included round, slender body, a male sexual organ that is perfect in 
every respect, a round belly, a slim abdomen and other marks such as shrivatsa, swastika, and lalita symbols in addition to chakras (Jaini 1961: 17-18).

The Buddha was aware of being observed by humans, gods, and various beings. The Mahavastu describes how hosts of gods came to view the Buddha while he was in mother's womb and indicate that he was aware of it. The newly born Buddha is depicted to as fully mindful and able to speak ${ }^{2}$. We also get to know the stories of Brahmans Vakkali and Brahmayu who became obsessed by Buddha's beauty and physical presence and finally joined the samghas. In fact, the Buddha at one point was forced to rebuke Vakkali and asked him what he saw in His body and that one who sees the dhamma sees $\mathrm{Him}^{3}$. A comparison of the Buddha with the lion recurs throughout Indian Buddhist literature. Samyutta Nikaya compares him to a mighty lion emerging from his lair and stretching himself. He roars and all animals who hear him are terrified. Similarly, when a Buddha arises in the world, many gods are filled with fear because he is more majestic and mightier than any one of them.

What could these accounts of Buddha mean to his followers? Apparently, Buddha's perfect body and abilities held out a promise to his populace at large: (1) it served to persuade sceptics of his claims to ultimate authority (Powers 2012: 22); and (2) convinced followers that they could also transcend the harsh realities of the flesh: through austerities and accumulation of good karma over many life times, The Buddha had progressively developed a body that was ideally suited to religious life. His followers were in a sense assured that their practice can lead to not just acquisition of a perfect body but also the merits that came with it, such as the promise of redemption from the cycle of birth and death.

\section{REFLECTIONS WITHIN JAIN TRADITION}

Even though Jain tradition is not as vocal about tirthankara's (Jain spiritual teachers) masculinity, the fact remains that attributes associated with ideal males abound in the stories of their leaders. There is a story of how as a child Mahavira subdued a terrifying snake by the means of his great courage and peaceful aura (Jaini 1977). As a prince of a royal household, he, too, must have gained proficiency in archery, mathematics, and so on though much is not elaborated on it. What we are certainly aware is that his post renunciation wanderings without clothes and subsequent penance would have brought out his grit and determination befitting a man of incalculable strength. Mahavira's determination to go without clothes in the severest of the weathers and locales would have impacted notions of masculine constructions in at least two ways: (1) demonstration of limitless vigour; and (2) exhibition of a perfect male body. The latter began to permeate imagination of Digambara exponents in pervasive ways and they studied human anatomy more intensively and extensively than any other early Indian religious tradition.

Not Just the Buddha or Mahavira, even the monks are extolled for their strength, virility, and even martial qualities, all of which help them in their religious pursuits. The Thera-Gatha gives us the example of Piyanjaha, who had been a king and whose warrior courage enabled him to live in forest without fear ${ }^{4}$. A number of tales recount abandoned wives to win back their husbands using their sexuality. Vira who is described as outstanding athlete and warrior left his wife to attain arhat-hood. His wife attempted to seduce him, but he spurned her saying, "this woman trying to tempt me is like a person trying to shake Mt. Meru with a wing of a gnat" ${ }^{\text {. }}$.

\section{MONKS: IMAGING MANLY PERFECTION}

Not just the Buddha, even the monks were extolled for their strength, virility, and even martial qualities, all of which helped them in their religious pursuits. Buddhagosha, the fifth-century Buddhist monk and 
writer states that a well-trained monk is like a "mighty king of panthers" (mahadipiraja), who hides in tall grasses and watches his prey, such as a buffalo. In the same way, a bhikku must devote himself to meditation in forest.

There are many other depictions of monastic followers as paragons of masculinity. Shariputra is often singled out as "a general, a hero, a meditator" and whose deeds elicited repeated praise in the Thera-Gath ${ }^{6}$. Similarly, the Udana informs us that Shariputra was a mighty man of great power and majesty who could bear Mara's blow without much distraction (Steinthal 1948: 39-40). The ideal state of mind for monk is one when the masculine monk has developed complete detachment from the world and removed familial ties. The Thera-Gatha (II. 36) gives us the example of Piyanjaha, who had been a king and whose warrior courage enabled him to live in forest without fear. A number of tales recount abandoned wives to win back their husbands using their sexuality. An example of the proper monastic mind set was Mahatissa, who once encountered a beautiful woman on the road after she left her abusive husband. She sought to attract the monk by her charm but the monk remained firm in his monastic purpose. Later when her husband enquired of him whether he saw a beautiful woman on road, his response was that he had only seen a heap of bones passing the other way.

The dangers and terrors of wilderness are described in great details. These include extreme cold and heat, rain, thunder, and other weather phenomenon, bandits and other dangerous people and even attempted seductions by women, all capable of causing harm. The notion that ordinary people find these phenomena terrifying is continuously highlighted in Indian Buddhist literature, and a number of monks are praised for their ability to maintain perfect equanimity in situations that would reduce most humans to abject fear. The monks are trained to confront suffering throughout their worldly existence and to inculcate physical and mental discipline. The Buddhist notion of masculinity for monks espouses the ideas of physical toughness, alertness, focused attention, detachment and a complete control over bodily desires. There is recognition that human body is a site of "impurities" that range from diseases to desires and only meditation can rein those in. A strong body and focused mind is therefore a condition to eventual enlightenment.

\section{RELATIONAL CONSTRUCTION OF MASCULINITY}

Even as one is able to gradually construct Buddhist and Jain notions of masculinity based on image projection of the Buddha, the Ultimate Man and Mahavira, and other monastic prerequisites, there are aspects that leave room for speculation on Buddhist and Jain notions of the feminine and on third gender (sexual deviants). The constructs of masculinity within heterodox traditions are certainly relational to their notion of femininity. The reformist tendency of the heterodoxies that derived naturally from their attacks on Brahmanical privilege and pretensions came a cropper when they had to deal with women's issue. Although Buddhist and even Jain thinkers were willing to reject the notion of hierarchical social order or question the efficacy of countless Brahmanical ceremonies, the power of patriarchal doctrine of male supremacy, in all matters, proved harder for them to escape.

Buddhist literature depicts men as irresistible to women and the unwanted advances of women undermine the resolve of monks to remain celibate. As Serenity Young Puts it, "women try to impede their progress: women are the opposition, women are not participants in the same journey but are obstacles to it..." (Young 2004: 5). So, who is an ideal woman, according to Buddhist and Jain literature? The ideal image for women suggested in the heterodoxies, especially amongst Buddhists and Digambaras, is the 
one who should be subordinated to men on account of their being injudicious, lustful, and fully capable of using their wiles to seduce men. In this, Buddhists and Jain perceptions hardly appear different from Brahmanical patriarchal notions.

In Anguttara Nikaya, the Buddha is said to have warned young monks, "Monks I know of no physical appearance that reduces a man's mind to slavery as does that of women... ...the minds of men are completely obsessed with women's cresses". In another sermon in the same collection, the Buddha turns to the same theme:

Monks women ensnare the minds of men: whether walking, standing still, sitting, or lying down whether laughing, talking singing or crying, whether sick or dying, women ensnare the minds of men. The most powerful factor undermining their resolve to live of holy life, that is, life of celibacy was the unwanted advances of a woman.

The Vinaya Pitaka informs us that Buddha issued a norm prohibiting monks from traveling alone with women ${ }^{7}$. Serenity Young notes it that the Buddha biographies identify women as materiality (samsara) and sexuality, in contrast to men who are associated with spirituality (dharma) (Young 2004). There was then a need to domesticate them and show them their position. Similarly, Digambara Jain tradition, too, questions a female's ability to gain liberation. It is suggested that the fickleness of women's nature impedes meditation and that would not allow her to have spiritual ascension to the abode of siddhas ${ }^{8}$.

The company of females was castigated within Buddhist monastic norms but that of men encouraged. In fact, monastic friendship was regarded as essential for men pursuing the goals of the Buddhist path, which included serenity, equanimity, attainment of trance states, wisdom (stream enterer, once returner, non-returner, and arhat), and the final bliss of nibbana. In the Samyutta Nikaya, the Buddha responded to Ananda's query on friendship by stating, "Friendship is more than half the holy life; it is the entire holy life". Relationships between men and women were characterized as fraught with tensions, misunderstandings, and conflicts and a threat to peace of mind. The constructs of male camaraderie receive a different treatment. Male bonding was envisioned as reasonably problem-free, in fact, conducive to the life of a monk who needs to travel, meditate, debate, and live with fellow monks without getting emotionally involved. Therefore, Monastic existence did not construe to be an entirely isolating experience. For instance, the Buddha and Ananda constitute idealized figures of solidarity. It is interesting to note that such friendship amongst nuns did not seem feasible on account of "the dangers of potential sexual attraction" (Powers 2012: 142).

\section{TREATMENT OF SEXUAL DEVIANTS}

The ideal presentations of male bonding stand as a contrast to Buddhist dealing of sexual deviants. Once again, Buddha's radicalism appears circumscribed. The Buddhist position does not appear fundamentally different from that of other current traditions including both Jainism and Brahmanism. Heterosexuality is accepted as the "normal sexual" paradigm and those digressings are not acceptable.

Leonard Zwilling found a variety of words in Indian Buddhist terminology to designate sexually non-conforming men who share the common trait of "lacking maleness" (Zwilling 1992). The term found most often in Buddhist literature is pandaka, a word Zwilling metaphorically translates as "without testicles" (Zwilling 1992: 204). Pandakas have also been equated with eunuchs but Zwilling has shown that the various subtypes of pandaka that have been mentioned in the texts range from chronically impotent, voyeurs, temporarily impotent to those using artificial means of satisfying themselves and the implication of a eunuch may not befit these. Barring the chronically impotent ones, others were capable of partial sexual pleasures. However, they did not meet 
the normative sex roles of the adult male; of satisfying a sexually voracious woman or procreating to sustain family lines. They may be then referred to as napumsaka. But they may be sexually active in their own way, possibly like homosexuals. Buddhaghosa's commentary on Pali monastic code of conduct goes into considerable detail on the physiology and psychology of pandakas asserting that such people were unquenchable (avupasantaparilaha) in their lust (ussanakilesa), just like coarse young girls (thulakumarika) and street prostitutes (vesiyas). As males who failed to play socially normative gender roles, the pandakas were denied ordination as monks. Vasubandhu informs us that they were incapable of religious discipline (samvara), modesty, and shame


were also denied ordination in the sangha. All these monastic rules were laid down in the Vinaya Pitaka. The rules about pandakas were delineated by the Buddha himself in response to the negative public opinion of the monastic order. The charge that monks were behaving in an undisciplined and depraved way was being levelled. One of the stories describes a pandaka, just admitted to the order, going up a group of young monks and asking them to "defile" him. They sent him back, upon which he went to elephant keepers who satisfied him but thereafter criticized the order for promoting such behaviour. The Master then decided against admitting pandakas. Historians have varied ways to explain this. According to Frits Staal, the cause for exclusion of pandakas had nothing "to do with murky reasonings... with regards to homosexuals". It was merely a practical decision. It was not easy to decide whether a pandaka must be regarded as a male or a female and the difficulty arose where they should be housed; in monasteries or nunneries (Staal 2009: 323). The issue of public funding to the monasteries implied that the populace needed to be placated and popular notions of sexuality be adhered to. Interestingly even as the category of transvestites and homosexuals was acknowledged, these remained an aberration to the current notion of masculinity and hence pushed to the margins of social existence.

While references to shifting forms, transposed genders, sexual masquerade, and same sex relationships abound in both Brahmanical and Buddhist literature of early India, it was among the Jains that the nature of third sexed individuals was thoroughly debated upon. Speculations by the religious scholars on the characteristics attributable to different sexes arose in the context of examining the relationship between the natural gender and grammatical gender. Such a relationship was premised on the assumption that all objects as well people were gendered by the presence of certain defining characteristics and expressed through a single term ling $a$. By the third century BCE, a person's gender could be defined by one of the three terms; purusha, stri, and napumsaka. The Brahmanical and Buddhist position on the gender was largely defined by a person's ability to procreate, hence impotency implied that the individual would be characterized as napumsaka. The criterion of reproductive capacity was, however, questioned by Jain system of thought as prepubescent and post-menopausal women could not procreate. They arrived at distinct markers of gender identity. As Zwilling and Sweet (1996) had shown, Jains sought to make a very nuanced distinction between "biological sex" or dravyalingam with "material (sexual) mark" and bhavalingam (mental [sexual] mark) which is basically an attempt to comprehend the psychic frame of individuals. Those who were men but were psychologically females were referred to as manushyini. Further, they distinguish between masculine napumsakas (purushanapumsaka) and feminine napumsakas. What distinguished the feminine from the masculine, given their somewhat similar looks, was their sexual practice-whether they were merely receptive partners in sexual intercourse (feminine) or both receptive and penetrative (masculine) with the 
penetrative determining the masculine characterization (Reddy 2005: 20).

The exercise was also a part of a larger debate on spiritual liberation of women (strimoksha). Their attempt to define women led them to closely look at other possible sexual categories such as those of the napumsaka such as jatinapumsaka (congenital hermaphrodite), kritimakhliba (one who has been rendered a hermaphrodite, possibly through castration, hence a eunuch), and hunda (one with deformed body). The position of Shvetambaras was that they did not mind to enter the samghas as they would be clothed but for the Digambaras, a non-hunda, manushyini, jatinapumsakakritikhliba, on account of genital deformity would not be allowed to become a mendicant. The position clearly emphasizes the "aspect of biological gender in the assumption of mahavratas (vows) and attainment of moksha". In this respect, the status of a non-congenital hermaphrodite in the Digambara tradition would be similar to that of a woman ${ }^{11}$. It is noteworthy that even those traditions that proscribe a sexual existence in their respective samghas needed to define individuals on the basis of their sexual identity. Only a "complete" man or woman, capable of heterosexual relationships, would be admitted in.

\section{RATIONALE OF MASCULINE REITERATION}

Prima facie, it may appear ironic that while only a "complete man" could be declared fit to enter samhga, he had to actually lead a celibate asexual existence. However, such regulations can be reconciled in a couple of ways: (1) spiritual leaders and followers of heterodox sects believed in current dominant notions of masculinity that fitted within larger frames of patriarchy and so reiterated those; (2) the monastic prerequisite of physical strength and complete control of desire was essential for a subsequent harsh ascetic existence; and most importantly (3) within both traditions a clear sexual identity had to be established before negating it. Construction of perfect body and masculine images of certain types became foundational to religious philosophies of both Buddhism and Jainism. In one of the stories, the Buddha rebuked a monk for destroying his sex organs and told him that the dhamma reiterated the need to control desire by mental and spiritual discipline, not by physical removal of its cause. The eventual negation of the masculine self would certainly come within monastic context but the process was deemed to be slow and difficult one and had to be preceded by its affirmation.

\section{CONCLUSIONS}

Finally, can we apply Connell's notions of hegemonic and subordinate masculinities in a discussion on masculinities within the frame of heterogeneous traditions (Connell 1995: 67-81). There is no doubt that these are fairly modern and Western concepts and the application of these on early Indian setup may not be very fair. Nonetheless, this frame does allow us to locate a certain type of hierarchy in existing social and religious traditions. We get to know that men could be of different types and ideal construction could vary from culture to culture. The notion of hegemonic masculinity brings with it a clue to hierarchy and power. The power may or may not be political. It could extend to the domain of spirituality where the reference to Ultimate Men could convey an idea of inspirational perfection. Without doubt, both Mahavira and Buddha were projected as perfect men and, therefore, held the power to attract a following. Similarly, and more cogently, the idea of subordinate masculinity fits in very well in their concepts of impotent men, homosexuals, or transvestites all of whom were barred from entry into the samghas. In short, the literature of the two traditions inform us that there were masculinities of various kinds: the perfect and not so perfect. 


\section{Notes}

* This has been a part of a project sponsored by Indian Council of Historical Research, New Delhi that was completed in 2016. The title of the project was "Masculinities in Early India: The Possibility of a Discourse".

1. Dighnikaya, III. 144-145.

2. Mahavastu, II. 18.

3. Samantapasadika, I. 254.

4. Thera-Gatha-Attahakatha, vol. II. 36.

5. Ibid, vol. I. 52-53.

6. Ibid, vol. I. 99.

7. Vinaya Pitaka, IV. 132-133.

8. Yuktiprabodha. 24, cited in P. Jaini, Gender and Salvation, p. 169.

9. "Magga-Samyautta”, Samyutta Nikaya, V. 2.

10. Abhidharmakosa, IV. 43.

11. For details cf. P. Jaini, Gender and Salvation, pp. 148-158.

\section{References}

Connell, R. W. 1987. Gender and Power: Society, the Person and Sexual Politics. Stanford: Stanford University Press. - 1995. Masculinities. Cambridge: Polity Press.

Doniger, W. and B. Smith, eds. 1991. Laws of Manu. New Delhi: Penguin Classic.

Freer, L., ed. 1960. Samyutta Nikaya (Connected Discourses of the Buddha). Vol. 6. London: Pali Text Society.

Jaini, P. S. 1977. The Jaina Path of Purification. Delhi: Motilal Banarasidass Publishers.

- 1991. Gender and Salvation: Jaina Debates on the Spiritual Libertaion of Women. Delhi: Munshiram Manoharlal Publishers Pvt. Ltd.

—, ed. 1961. Malindapanha Tika. London: Pali Text Society.

Monier-Williams, M. 1999. A Sanskrit-English Dictionary. Delhi: Motilal Banarasidass.
Oldenberg, H. and R. Pischel, eds. 1966. Theragatha (Verses of the Elder Monks). London: Pali Text Society.

Powers, J. 2012. A Bull of a Man: Images of Masculinity, Sex, and the Body in Indian Buddhism. New Delhi: Dev Publishers and Distributers.

Reddy, G. 2005. With Respect to Sex: Negotiating Hijra Identity in South India. Chicago: University of Chicago Press.

Rhys Davids, T. W. and J. E. Carpenter, eds. 1889. Digha Nikaya (Long Discourses of the Buddha). Vol. 3. London: Pali Text Society.

Senart, E., ed. 1977. Mahavastu, Mahavastu-Avadana. Paris: I'Imprimerie Nationale.

Shastri, D., ed. 1981. Abhidharmakosa of Vasubandhu. Patna: K. P. Jayswal Research Institute.

Staal, F. 2009. Discovering the Vedas: Origins, Mantras, Rituals, Insights. New Delhi: Penguin Books.

Steinthal, P., ed. 1948. Udana. London: Pali Text Society.

Takakusu, J. and M. Nagai, eds. 1968. Samantapasadika of Buddhaghosha. Vol. 5. London: Pali Text Society.

Young, S. 2004. Courtesans and Tantric Consorts: Sexualities in Buddhist Narrative, Iconography, and Ritual. New York: Routledge.

Zwilling, L and M. Sweet. 1996. "'Like a City Ablaze': The Third Sex and the Creation of Sexuality in Jain Religious Literature." Journal of History of Sexuality 6(3):359-384.

Zwilling, L. 1992. "Homosexuality as Seen in Indian Buddhist Texts." Pp. 203-214 in Buddhism, Sexuality and Gender, edited by J. I. Cabezon. Delhi: Sri Satguru Publications.

\section{Bio}

Smita Sahgal, Ph.D., associate professor, Department of History, Lady Shri Ram College, University of Delhi, New Delhi, India; research fields: masculinity studies, history of religion, Indian theology, gender studies, early Indian social history. 